УДК 657.411

\title{
РОЗРОБКА УПРАВЛІНСЬКИХ РІШЕНЬ ЩОДО УПРАВЛІННЯ ВЛАСНИМ КАПІТАЛОМ НА ПІДПРИЕМСТВІ
}

\section{DEVELOPMENT OF MANAGEMENT DECISIONS ON OWN CAPITAL MANAGEMENT AT THE ENTERPRISE}

\author{
Парій Людмила Віталіївна \\ кандидат економічних наук, доцент, \\ Державний університет телекомунікацій \\ ORCID: https://orcid.org/0000-0002-7070-2521 \\ Parii Liudmyla \\ State University of Telecommunications
}

\begin{abstract}
У статті розглянуто розробку управлінських рішень щодо управління власним капіталом на підприємстві. Нині загострюється боротьба між підприємствами за володіння значної частки ринку та отримання якомога високих прибутків. Вихід з існуючого положення вбачається в обгрунтуванні адекватних управлінських рішень щодо управління підприємств на довгострокову та короткострокову перспективу. Тому оцінка впливу управлінських рішень на управління власним капіталом на підприємстві та визначення основних пріорітетних напрямків діяльності є досить актуальною проблемою в сучасних умовах. Досягнення цієї мети можливе лише за рахунок підвищення конкурентоспроможності. Тільки маючи конкурентні переваги підприємство зможе активно взаємодіяти з зовнішнім середовищем та мати змогу постійно розвиватися.
\end{abstract}

Ключові слова: власний капітал, управління, управління власним капіталом, управлінські рішення, конкурентоспроможність.

В статье рассмотрены разработку управленческих решений по управлению собственным капиталом на предприятии. Сейчас обостряется борьба между предприятиями за обладание значительной доли рынка и получения как можно высоких прибылей. Выход из существующего положения видится в обосновании адекватных управленческих решений по управлению предприятий на долгосрочную и краткосрочную перспективу. Поэтому оценка влияния управленческих решений на управление собственным капиталом на предприятии и определение основных приоритетных направлений деятельности является весьма актуальной проблемой в современных условиях. Достижение этой цели возможно лишь за счет повышения конкурентоспособности. Только имея конкурентные преимущества предприятие сможет активно взаимодействовать с внешней средой и иметь возможность постоянно развиваться.

Ключевые слова: собственный капитал, управление, управление собственным капиталом, управленческие решения, конкурентоспособность.

The article describes development of managerial decisions regarding capital management at the enterprise. Nowadays, the struggle intensifies among enterprises for market getting and high profit. The solution of this situation is the rationale behind the decision on long-term and short-term management of enterprises. That's why assessment of the impact management decisions on the management of own capital at the enterprise and determining the main priority areas is an extremely important issue in modern conditions. The achievement of the goal is possible only by increasing competitiveness. If a company has competitive advantages, it will be able to actively interact with the external environment and be able to constantly develop. This is facilitated by effective action of management staff to make appropriate decisions what ensures the financial independence of the enterprise from external sources of financing and guarantees financial stability and affects the level of competitiveness of the enterprise; to create and manage opportunities; willingness of the management team to make changes, to take risks; formation of the actual potential of enterprises. Effective action of economic entities in Ukraine requires management of financial resources, at the expense of own capital of the enterprise which will involve bases for stable development of the enterprise and its constant growth in the market. The basic notion which lay at the heart of the system is "the cost of capital". Therefore, every decision related to the management of equity must be made in terms of its impact on the value of 
the enterprise in general. Experience by domestic enterprises shows that investors prefer those companies where effective equity management operates, which will protect the interests and show the effect of the use of their investments. Capital is necessary attribute of the enterprise\&apos;s activities from the moment of creation of the company to its liquidation or reorganization. In this way managerial efficiency is very important for the enterprise.

Keywords: equity, management, equity management, management decisions, competitiveness.

Постановка проблеми. Дослідження проблем впливу управлінських рішень щодо управління власним капіталом підприємства зумовлене потребами гнучкого та адаптивного реагування на зміни у конкурентному середовищі. На сьогоднішній день актуальним залишається питання впливу управлінських рішень на розвиток підприємства задля постійного пошуку організаційних заходів щодо якісного управління власним капіталом підприємства.

Аналіз останніх досліджень і публікацій. Варто зазначити, що досліджуваній проблематиці приділяється особлива увага, про що свідчить широкий перелік наукових досліджень. Серед них варто відзначити праці Вергал К.Ю., Джур О.Є., Заїки Ю.А., Касьянової Н.В., Колосок В.М., Котляревського Я.В., Люльов О.В., Рогози М.Є., Савельєвої Т.М., Сопільник О.В. Вплив управлінських рішень на розвиток власного капіталу підприємства це багатоаспектний i інтегрований процес який потребує розробки системної методології обгрунтування такими процесами.

Виділення невирішених раніше частин загальної проблеми. У зв'язку з переходом на ринкову економіку на підприємства покладенні завдання щодо розробки стратегічних планів та самостійне визначення підприємством напрямів його розвитку. Тому актуальним у даному питанні $€$ вирішення проблем управління власним капіталом, що $є$ основним джерелом, який сприяє ефективній діяльності тобто забезпечує фрінансову незалежність підприємства від зовнішніх джерел фрінансування та забезпечує фрінансову стійкість, і впливає на рівень конкурентоспроможності підприємства.

Формулювання цілей статті (постановка завдання). Мета організаційного забезпечення полягає у створенні максимально сприятливих організаційних умов для ефективного управління розвитку підприємства. Реалізація мети організаційного забезпечення здійснюється за допомогою існуючого організаційного потенціалу задля виконання поставлених завдань до котрих слід віднести:

- підтримка стабільного та збалансованого срункціонування системи управління підприємства;
- реалізація запланованих заходів та бізнес-програм за рахунок використання економічного, соціального, науково-технологічного та природного потенціалів, концентрації інтелектуальних ресурсів;

- структурна організація взаємозв'язків між окремими елементами та ліквідації відхилень, що можуть виникати внаслідок змін, які визначаються впливом внутрішніх та зовнішніх чинників;

- організаційне забезпечення реалізації процесів інноваційних напрямів розвитку підприємств.

Виклад основного матеріалу дослідження. Узагальнення наукових здобутків, сприяло розумінню структури організаційного забезпечення, що складається із керуючої системи (суб'єкт змін, або ж суб'єкт, що визначає зміни) та керована система, тобто та, що підлягає впливу процесу управління (об'єкт змін). Внаслідок такого впливу в кінцевому підсумку ми отримує новий об'єкт, тобто результат організаційних заходів. Реалізація відповідного процесу потребує наявності таких підсистем: підсистему забезпечення, цільову підсистему та фрункціональну підсистему. Вони здатні забезпечити раціональне фрункціонування системи управління процесами розвитку підприємства, що відповідає можливостям та потребам реагувати підприємствам на зміни у зовнішньому середовищі. За певних обставин різні комбінації параметрів системи організаційного забезпечення можуть бути оптимальними або достатніми для успішного управління власним капіталом підприємства.

Отже, організаційне забезпечення виступає системою взаємовідносин організаційного характеру підприємства, що виникають через зміни, що відбуваються у процесі управління фрінансово-господарською діяльністю між елементами суб'єкта господарювання. Організаційне забезпечення $€$ невід'ємною частиною організаційно-економічного механізму управління розвитком підприємства і виконує роль з'єднувальної ланки у процесі управління розвитком підприємств.

Структура організаційного забезпечення управління розвитком підприємства з погляду комплексного підходу наведено на рис. 1. 

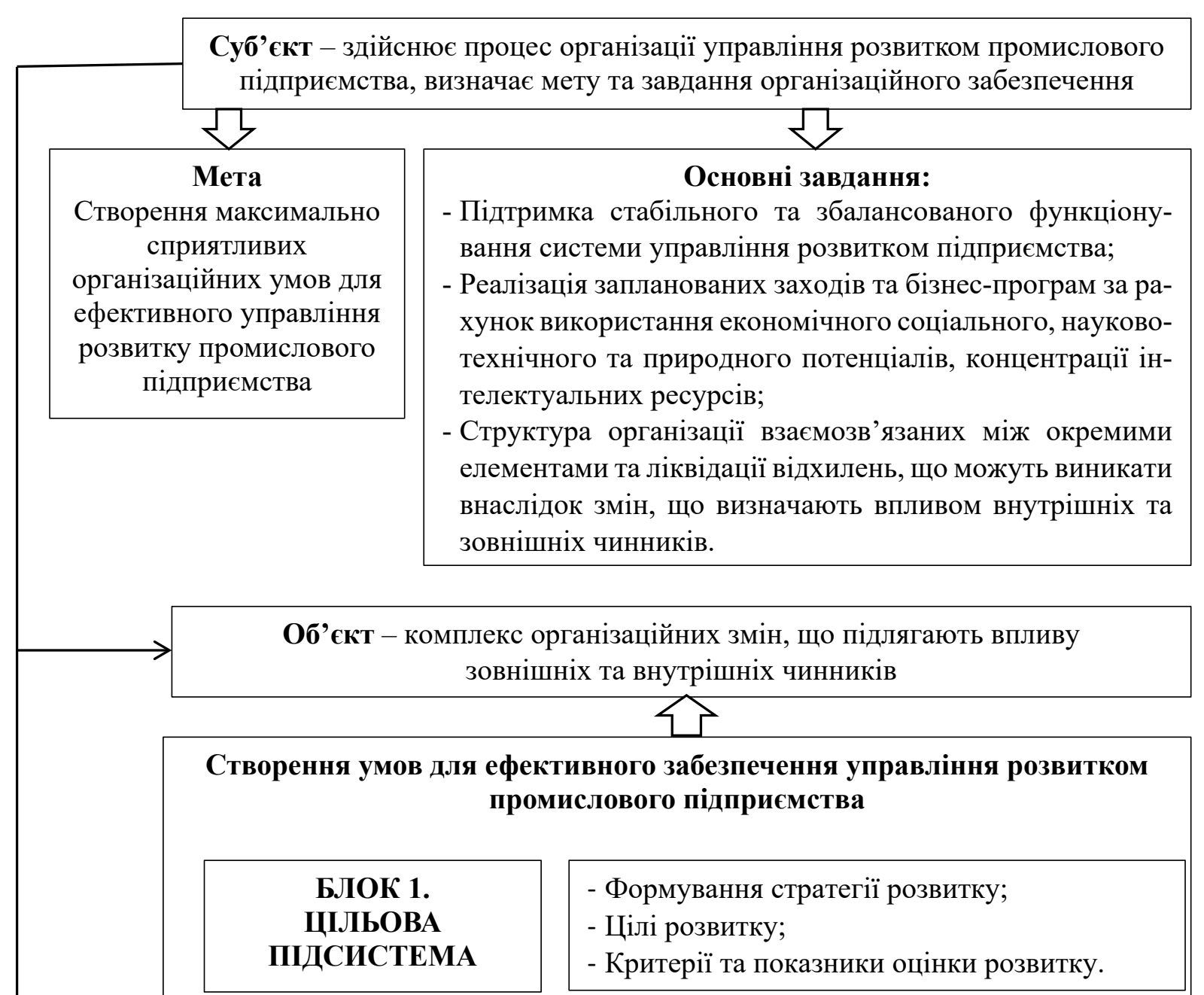

- Формування стратегії розвитку;

- Цілі розвитку;

- Критерії та показники оцінки розвитку.

\section{БЛОК 2. \\ ПІДСИСТЕМА \\ ЗАБЕЗПЕЧЕННЯ}

Результати, отримані від організаційних заходів управління розвитком промислового підприємства: економічні, соціальні, інноваційні, корпоративні

Рис. 1. Комплексний підхід до обгрунтування побудови системи організаційного забезпечення управління розвитком підприємства

- Принципи побудови системи організаційного забезпечення: планування, мотивації, організації, контролю, координації;

- Функції організаційного забезпечення;

- Процес організаційного забезпечення управління розвитком підприємства;

- Рівень корпоративної культури та готовність персоналу до змін.

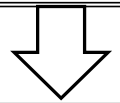

- Ресурсне забезпечення;

- ннформаційне забезпечен

- Організаційні методи та інструменти (організаційна структура підприємства; система мотивації персоналу).

ФУНКЦІОНАЛЬНА ПІДСИСТЕМА 
Схему, що демонструє найважливіші складові системи організаційного забезпечення управління розвитком підприємства має сприяти тому, щоб усі елементи фрункціонували у стратегічному режимі. Характер складових може визначати [1, с. 66]:

- елементи, які існують постійно і визначають склад підрозділів та взаємозв'язків в організаційній структурі управління;

- тимчасові структури, які забезпечують внутрішню підпорядкованість системи управління розвитком підприємств та вдосконалення взаємозв'язків в середині цієї системи;

- регламентуючі процедури, форми, методи та процеси, які використовуються в процесі управління розвитком підприємства.

Організаційному забезпеченню управління розвитком підприємства, як забезпечуючому структурному елементу системи управління підприємством, властиві власні суб'єкти та об'єкти, на які спрямована управлінська дія. Суб'єктом організаційного забезпечення процесу управління розвитком підприємства $€$ ланка або сукупність взаємопов'язаних підрозділів підприємства, котрі за допомогою різноманітних фоорм організаційного впливу забезпечують розробку, балансування та реалізацію окремих складових стратегії розвитку.

Суб'єкт це елемент, що керує процесом змін. I кінцевий результат зміни, тобто перетворення фоорми, складу, змісту; способи з'єднання елементів виробничої системи, характеру зв'язків між ними; кількість, якість та структура організаційного елементу або організації загалом за певний час [2, с. 6].

Суб'єктами організаційною забезпечення управління розвитком підприємства виступають менеджери, працівники, персонал, власники, тобто ті особи, котрі здійснюють вплив на об'єкт розвитку (зміни в системі) та визначать мету, завдання, забезпечують створення умов для ефрективного управління розвитком підприємства через формування цільової підсистеми, підсистем забезпечення та функціонування.

Об'єктами системи організаційного забезпечення виступають організаційно-оформлені елементи, зміни та фрактори управління, котрі наявні та ті, що створюватимуться у відповідності до вимог обраної стратегії розвитку. Об'єкти підлягають впливу комплексу організаційних змін, що виникають внаслідок зовнішніх і внутрішніх чинників. Під організаційними змінами слід розуміти перехідний етап між двома станами стійкості. Перелік об'єктів, що підлягають організаційним змінам визначається стратегією розвитку і може бути наступний:
- організація ресурсного забезпечення процесів розвитку: організація роботи з персоналом та кадрами, організація фрінансового, інсрормаційного та матеріально-технічного забезпечення;

- організація роботи 3 клієнтами та ринками: зворотній зв'язок з клієнтами, просування товару на ринок, пошук нових можливостей, ніш на існуючих та нових ринках;

- організація впровадження інновацій, реалізація бізнес-процес і в, удосконалення існуючого виробництва тощо.

Варто відзначити, що внаслідок впливу організаційних заходів, об'єкти до втручання та після нього не $є$ одними і тими самими. Внаслідок зміни можемо також отримати об'єкт 3 іншими параметрами, шо опиняється на більш високій сходинці розвитку, коли покращуються його якісні та кількісні виміри. Л може бути така ситуація, коли ми змінюємо об'єкт, але ця дія згубно впливає на нього, внаслідок чого він погіршується кількісно чи якісно (в історії бізнесу € достатня кількість прикладів, коли провальні управлінські дії доводили підприємство до банкрутства) [5, с. 6-7].

Формування стратегічного організаційного потенціалу досягається за допомогою розробки та впровадження стратегії розвитку загального управління та підпорядкованих їй фрункціональних стратегій. Це знаходить вираз у таких діях [4]:

- фрормуванні стратегічно-орієнтованого підприємства з відповідною структурою, здатною досягти визначених цілей;

- організації діяльності фрірми згідно з встановленими цілями та стратегіями;

- організації стратегічного управління діяльністю підприємства (організації), в тому числі за допомогою перебудови діяльності всіх ланок для роботи у стратегічному режимі;

- реорганізації як усієї оргструктури управління, так і окремих лапок, згідно з потребами ринку та стану зовнішнього середовища.

Цільова підсистема визначає саму стратегію розвитку чи їх комбінації, цілі стратегічного розвитку підприємства, орієнтується на потенційні результати розвитку та критерії оцінки розвитку. Проте, внаслідок зміни стратегії розвитку підприємства відбувається зміна пріоритетів у бізнес-процесах і самій організаційній структурі.

Варто відзначити існування великої кількості стратегій розвитку, однак як правило підприємства використовують їх комбінації. В залежності від того, яку стратегію було обрано і який напрям діяльності вона охо- 
плює визначаються і цілі організаційного забезпечення. Так, для прикладу: якщо за основу взято стратегію посилення позиції на ринку - то основними цілями організаційного забезпечення буде процес пов'язаний зі зміною існуючого стану на бажаний, зокрема освоєння нових ринків, нового продукту за існуючого технологічного рівня та положення фрірми в середині галузі; стратегія розвитку ринку -організація усіх цілей передбачає пошук нових можливостей покрашення свого положення на ринку; розвитку продукту організація усіх цілей пов'язана з можливою горизонтальною інтеграцію [2, с. 109-110].

При впроваджені організаційного забезпечення управління розвитком підприємства треба зважати на те, що цілі традиційних організаційних систем відрізняються від стратегічно-орієнтованих. Специфіка цих цілей ґрунтується на тому, що вони мають співпадати із стратегічними цілями розвитку чи безпосередньо цілями стратегії розвитку. Однак, на відміну від різноспрямованих цілей розвитку підприємства, цілі організаційного забезпечення управління розвитком мають бути взаємопов'язані та мати управлінське спрямування. Наприклад, цілями окремих стратегій (із загального «стратегічного набору» організації) можуть бути: «створити та впровадити у виробництво нову продукцію» (з конкретизацією - яку саме), «залучити та перепідготувати персонал» (певної категорії та чисельності) тощо, - тобто цілі різних стратегій та стратегії як такі, що відрізняються між собою, знаходять вираз в окремих заходах стратегічних планів. Однак, у процесі виконання цих планів треба оптимізувати систему «час виграти», встановити контрольні точки, організувати роботу виконавців та співвиконавців і т. ін. Ці управлінські цілі впливають на зміст стратегії «розвитку загального управління», i, як наслідок на організаційне забезпечення системи управління, структуру системи управління стратегічними змінами [3]. Однією 3 принципових методичних дилем в організації управління розвитком підприємства $є$ оцінка ефрективності та якості управлінських рішень в процесі стратегічного розвитку. Тому критерії та показники оцінки ефективності управління розвитком підприємства з однієї сторони $є$ інструментом оцінки існуючого етапу, а з іншого підґрунтям для прийняття обґрунтованих управлінських рішень стосовно економічної поведінки підприємства у майбутньому.

В контексті організаційного забезпечення суб'єктами управління має бути розроблена методика оцінки результативності організаційних заходів та їх вплив на різноманітні сорери життєдіяльності підприємства, бізнес-процеси, що їх супроводжують у процесі стратегічного розвитку, а саме: фрінансова, управлінська, комерційна, технологічна, інноваційна, маркетингова, трудова, виробнича сорери тощо. У залежності від потреб оцінки та моніторингу результатів використовують різноманітні економіко-статистичні та математичні методи оцінки, зокрема: комплексну та інтегральну методику оцінки, систему збалансованих показників стратегічного розвитку, експертну оцінку, систему кореляцінного-регресійного оцінювання, системне моделювання тощо. За допомогою таких методів здійснюється технологічне, стратегічне, організаційне та інформаційне моделювання процесів управління розвитком підприємства.

Підсистема забезпечення включає в себе ресурси необхідні для організації процесів розвитку підприємства, інформацію, на основі якої приймаються усі управлінські рішення, нормативно-правову базу, що регламентує діяльність підприємства та його структурних підрозділів і сама організаційна структура підприємства, як спосіб організації елементів у систему, сукупність стійких зв'язків і відносин між ними, зокрема тих, що існують між підрозділами і працівниками підприємства.

Для досягнення мети організаційний процес має бути забезпечений такими видами ресурсів: фрінансові, виробничі, трудові, технічні засоби для обробки інфрормаційних ресурсів тощо. Інсрормаційне забезпечення полягає у здійснені збору, накопичення, аналізу та збереження інорормації, котра потрібна для виконання фрункцій всіх підсистем організаційною забезпечення щодо управлінням розвитком підприємства.

Управлінські рішення $є$ невід'ємною частиною управління та цілеспрямованого впливу на керований об'єкт чи процес. За їх допомогою реалізовується координація основних фрункцій структурних організаційних елементів, що у сукупності сприяють вирішенню поставлених завдань. Комплексне використання управлінських рішень створює сприятливі умови для фуункціонування та розвитку підприємства.

У підсумку до організаційного забезпечення управління розвитком підприємства висувається низка вимог, що мають бути спрямовані на забезпечення результатів організаційних заходів (рис. 3). 


\section{Стадії організаційного забезпечення управління розвитком підприсмства}

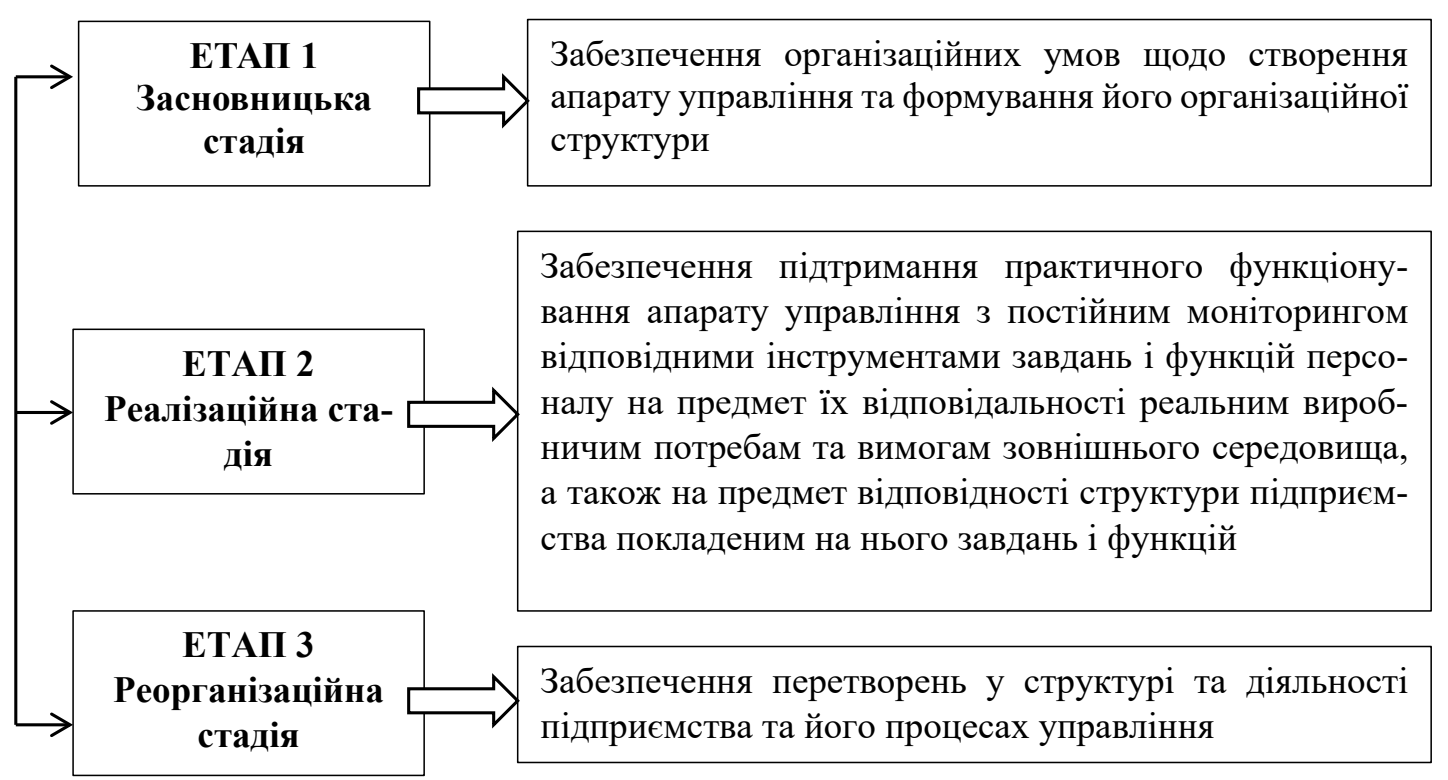

Рис. 2. Стадії організаційного забезпечення управління розвитком підприємства

Ефективна взаємодія структурних елементів суб'єкта господарювання та їх орієнтацію на досягнення кінцевої мети розвитку
Продуктивне використання усіх трудових ресурсів підприємства, котрі задіяні у процесі управління господарською діяльністю та забезпечують ії розвиток

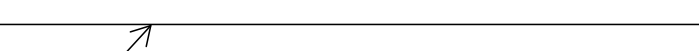

\section{Розробка та впрова- дження системи показни- ків ефективності функціо- нування об'єкта розвитку}
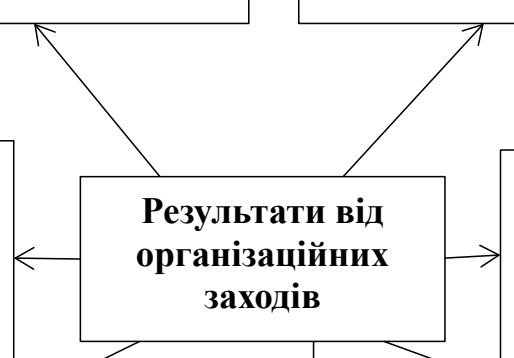

Удосконалення методики та процедури підготовки і прийняття різного роду управлінських рішень

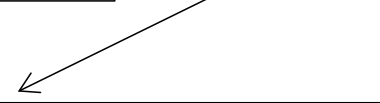

Здійснення системи організаційних заходів, що сприяють розширенню ініціативи, самостійності та відповідальності управлінського персоналу та працівників різних ланок за кінцеві результати їх діяльності
Удосконалення організаційного рівня підприємства та інформаційно-технічного забезпечення управлінського процесу

Рис. 3. Очікувані результати розвитку підприємства від реалізації організаційних заходів управління 
Висновки. Отже, для кожного підприємства не можливе ні подальше існування, ні його робота, якщо підприємство не забезпечене власними фрінансовими ресурсами. Ефективність діяльності підприємства значно залежить від розвитку та вдосконалення системи управління власним капіталом. Дослідження підходів щодо управління власним капіталом, які пропо- нують вітчизняні науковці, дозволило структурувати процес управління, що стало основою управління власним капіталом підприємства. Необхідним атрибутом діяльності підприємства завжди $€$ капітал, від моменту створення підприємства до його ліквідації чи реорганізації, тому важливим для підприємства $€$ ефрективність його управлінської системи.

\section{СПИСОК ВИКОРИСТАНИХ ДЖЕРЕЛ:}

1. Коваль О. С. Рекомендации по повышению эффрективности управленческих решений в предпринимательских структурах. Международный журнал экспериментального образования. 2016. № 10. С. 48-52.

2. Колпаков І. І. Методи управління. Київ : ЦУЛ, 2007. 638 с.

3. Кононенко О. Аналіз економічної звітності. Харків : Фактор, 2016. 156 с.

4. Легомінова С. В. Теоретичні та методологічні аспекти управління конкурентними перевагами телекомунікаційних підприємств : монограсрія. Київ : Міленіум, 2020. 380 с.

5. Орлів М. С. Підготовка і прийняття управлінських рішень : навчально-методичні матеріали. Київ : НАДУ, 2017. $40 \mathrm{C}$.

6. Соляник Л. Г. Фінансовий аналіз. Дніпро : НГУ, 2017. 67 с.

\section{REFERENCES:}

1. Koval O. S. (2016) Rekomendatsyy po povushenyiu effektyvnosty upravlencheskyh reshenyi v predprynymatelskyh strukturah [Recommendations for improving the efficiency of management decisions in business structures]. Internetional Journal of Experimental Education, no. 10, pp. 48-52.

2. Kolpakov I. I. (2007) Metody upravlinnia [Management methods]. Kyiv: TSUL.

3. Kononenko O. (2016) Analiz ekonomichnoi zvitnosti [Analysis of economic reporting]. Kharkiv: Faktor.

4. Legominova S. V. Teoretychni ta metodolohichni aspekty upravlinnia konkurentnymy perevahamy telekomunikatsiinykh pidpryiemstv [Teoretical and methodological aspects of managing the competitive advantages of telecommunications enterprises]: monograph. Kyiv: Milenium.

5. Orliv M. S. (2017) Pidhotovka i pryiniattia upravlinskykh rishen: navch.-metod. materialy [Preparation and decision-making: educational materials]. Kyiv: NADU.

6. Solyanik L. G. (2017) Finansovyi analiz [Financial analysis]. Dnipro: NHU. 